\section{Other Sections.}

In the Physiological Section Prof. Rudolf Cohn (Königsberg) described a new series of his investigations of the nature of the base obtained by the action of hydrochloric acid on albumen.

He obtained a body possessing the formula $\left(\mathrm{C}_{6} \mathrm{H}_{13} \mathrm{~N}\right)_{2}$, and isomeric with and similar to leucinimide, and probably possess. ing the constitution of dioxydibutyldiethylendiamine. The ease of the formation of such bodies may explain the occurrence of certain bases, such as spermine in the animal organism.

In the Section for Hygiene and Bacteriology an important discussion was inaugurated by Dr. Czaplewski on the method of using formaldehyde (formal, formaline) as a disinfectant.

A remarkable paper was contributed to this section by Dr. Weyl (Berlin) on the sterilisation of water by means of ozone. Water to be sterilised is pumped to the top of a tower and allowed to flow slowly over stones, meeting as it falls a curren of air charged with ozone.

In one experiment with Spree water containing 80,000 90,000 micro organisms per cc., 3000 litres of water were obtained in an hour, containing less than Ioo organisms per cc.

This process appears to be also effectual in purifying peat and bog water, the solution of the iron salts of humic acid being decomposed and oxidised, and the brown colour disappearing in consequence.

The method can be advantageously used in connection with filter-beds, by which the floating organic matter is removed from the water before it is treated with ozonised air.

The cost of sterilising an average river water works out at $\frac{1}{4} d$. to $\frac{1}{2} d$. per 1000 litres; no ozone remains in solution.

In the Physical Section an interesting paper was read by Dr. Carl Linde, on the industrial uses of liquid air.

Prof. Adami's disccurse, in the same section, was remarkable for demonstrating the possibility of constructing dynamos and galvanometers at the cost of a few pence, and the power of performing electrical experiments with the simplest materials. It is impossible in an abstract to give any idea of the charm of Prof. Adami's manipulations.

Prof. C. Kahlbaum's (Basle) experiments on the distillation of metals showed that most metals can be distilled in vacuo, vessels of glass or porcelain being used. Very remarkable is the fact that alloys can be fractionated by this method; in one experiment the copper was quantitatively separated from the nickel in a German coin, the nickel remaining in the flask as a silvery regulus, and the copper crystallising in the receiver; such newly-distilled metals resist to a greater degree the action of atmospheric oxygen.

Prof. Ostwald's paper on periodic changes in the rate of reaction was received with some scepticism, and produced a lively discussion. It appeared that pieces of a certain block of metallic chromium, 5 kilograms in weight, and prepared by Dr. Goldschmidt, showed a remarkable property.

When such pieces were placed in dilute hydrochloric acid, the numbers of the bubbles of hydrogen evolved in equal times, and measured in a capillary tube, exhibited a constant variation; thus in equal periods of time two, four, six and eight bubbles appeared respectively, and then the series recommenced with two bubbles. This truly remarkable phenomenon was confirmed by observations reaching over many months.

Unfortunately, this was the only specimen of metallic chromium which could be obtained possessing this curious property.

All the scientific sections were invited to a meeting in the Kailnstal, where Prof. Chun explained the exhibition of the results of the German Deep Sea Expedition.

These results confirmed in many cases the results obtained on the Challenger expedition, especially as to the existence of life at the greatest depth of the Antarctic Ocean.

When the explorers landed at Kerguelen they were immediately surrounded by great flocks of birds, showing no fear, and perching on the shoulder or pecking at the boots of the astonished members of the expedition.

Some of the fish found at depths of 3000 metres, to which depth naturally but little light penetrates, resembled those found in the Lias, representing a period when the atmosphere of the earth was dense, and charged with carbon; these fish were in some cases provided with special means of collecting light, being in possession of enormous eyes occupying nearly the whole side of the head, or supplied with telescopic organs; in other cases they carried their light with them on their heads, in a somewhat similar fashion to the glow-worm.

NO. I 568 , VOL. 6 I]
On Wednesday afternoon and on Saturday no meetings were held, and a large number of excursions were arranged, comprising visits to the lakes and watering-places near Munich, and excursion to the royal palaces and to Ratisbon.

On Thursday a gala-performance of "Lohengrin" was given at the Opera by royal command, for which every member of the Congress received a ticket.

During the whole week the picture galleries and exhibitions were open to the members at a reduced charge, and opportunities of visiting the breweries, ice-works, \&c., were afforded.

The accommodation of the guests was in the hands of a special committee, who performed their difficult task to the satisfaction of every one, the prices of the rooms being especially moderate.

The next meeting of the Society will be held in September 1900, at Aachen (Aix-la-Chapelle), and, being easy of access, should attract English men of science.

W. T. L.

\section{BOTANY AT THE BRITISH ASSOCIATION}

$T$ HE President of the Section (Sir George King) delivered an address in which he gave a comprehensive sketch of the history of Indian botany. Reports were presented by the committees on assimilation in plants and on fertilisation in the Phæophyceæ. In the former investigations-conducted by Dr. F. F. Blackman (Cambridge)-the experimental work dealt with the sources of the carbon dioxide of leaf assimilation, with the respiration of the stem as distinguished from the leaf, with the magnitude of the absorption of carbon dioxide from the soil, and with kindred problems, of which a preliminary account was given by Dr. Blackman at the Bristol meeting. Mr. Lloyd Williams (Bangor) had been engaged during the past year in researches into the cytology and life-history of various members of the Phæophyceæ, including Dictyota dichotoma, Halidrys szliquosa, Himanthalia lorea, Laminaria saccharina, Alaria esculenta and several species of Fucaceæ.

Mr. Williams contributed a preliminary note on the lifehistory and cytology of Halidrys siliquosa, in which he dealt with the formation and liberation of the sexual cells, the striking phenomena accompanying the act of fertilisation, the segmentation of the spore, together with the cytology of the various processes. In the process of fertilisation the most important points observed were (I) the gyrating, clockwise movement of the antherozoids; (2) the long time taken to effect fertilisation30-50 minutes as against 3-10 minutes in Fucus; (3) the peculiar behaviour of the egg at the moment of fertilisation, its distension and sharp rugged conical projections with beady threads emitted from their apices ; (4) the subsequent restoration of the egg to its normal shape and size.

In accordance with the usual custom, Friday afternoon was - devoted to a semi-popular lecture, which was this year delivered by Mr. Harold Wager, on the sexuality of the fungi. The lecturer gave an interesting and clear account, illustrated by lantern slides, of the phenomena of sexuality in the various groups of fungi.

An additional value was given to the lecture by the number ot new facts dealt with by Mr. Wager; these included some new observations on fertilisation in Peronospora barasitica and Polyphagus Euglenae.

Miss Ethel Sargant gave a demonstration of vermiform nuclei in the fertilised embryo-sac of Lilium Martagon (vide Proc. Roy. Soc., vol. lxv. p. 163, 1899).

Mr. J. C. Willis, Director of the Royal Botanic Garden, Peradeniya, Ceylon, gave an account of the research laboratory and of the facilities afforded to botanists conducting investigations in the Ceylon Gardens.

On Saturday, September I6, Mr. G. Dowker, the local secretary of Section $\mathrm{K}$, whose intimate knowledge of the Kent flora made him an admirable leader, conducted a botanical excursion to Sandwich. Those who were present at the meetings of Section $\mathrm{K}$ will learn with sincere regret that $\mathrm{Mr}$. Dowker died suddenly on Friday, September 22. The botanists present at Dover had learned in their short acquaintance with Mr. Dowker to appreciate his kindly nature and the keen interest he took in botanical work.

Thallophyta.

Prof. Marshall Ward gave an account of his recent work on Onygena equina, a horn-destroying fungus (Proc. Roy. Soc. 
vol. 1xv., 1899, p. 158). The genus Onygena comprises six species, all very imperfectly known, remarkable for their growth on feathers, hair, horn, hoofs, \&c., on which their sporocarps appear as drumstick-shaped bodies 5-10 mm. high. A cow's horn thoroughly infested with the mycelium of $O$. equina yielded material for the investigation; the author not only verified what little was known, but was able to cultivate the fungus, to trace its life-history, and to supply some details as to its action on horn. The development of the sporocarps, the structure, germination and biology of the chlamydospores were dealt with; also the details and development of the asci and the germination of the ascospores. Prof. Ward expressed the view that no trace of any morphological structure comparable to sexual organs could be discovered, though many: points suggest the alliance of this fungus with Erysiphere and the Truffles.

Mr. R. H. Biffen (Cambridge) presented an account of ${ }_{i}^{\circ} B u l$ garia polymorpha (Wettstein) as a wood-destroying fungus. Bulgaria polymorpha is stated by Ludwig to be parasitic on oak. The author has examined its anatomy, and studied it in pure cultures on wood and in food-material. The white early growth soon becomes bright orange; small rounded elevations are afterwards formed, which are incipient reproductive bodies. The action on wood was examined in some detail. The fungus grows better on oak than on pine. The lignified wood-elements are de-lignified. Details as to the reactions in various stages of its destructive action are dealt with in the paper. The author does not regard the fungus as of great importance as a wooddestroying organism in this country.

Mr. A. Howard (Cambridge) described some recent work on a disease of Tradescantia.

During the summer it was found that two species of Tradescantia, growing in greenhouses, were being attacked by a fungus. Diseased leaves and stems were in many cases found to be covered with long white conidiophores. Pure cultures were made of the parasite, which proved to be a species of Botryosporium. Some difficulty was experienced in obtaining this form free from another fungus, a species of Cladosporiun. It was found in the case of the naturally growing host plants that infection started either on the upper side of the leaf or from the margin. Tangential sections of the upper epidermis of the leaf, when grown in hanging drops, showed in all cases hyphæ on the epidermis, which gave rise to the same species of Cladosporium as that mentioned above, occurring as a weed in the Botryosporium cultures. The development of this Cladosporium was then followed out from a single spore by the hanging-drop method, and infection experiments were made which proved successful.

Prof. Potter (Newcastle) read a paper on a bacterial diseasewhite rot $\rightarrow$ of the turnip.

The author found in the early autumn numerous turnips, whose roots, when fully grown, became completely rotten. The rotten portion presents a white glazy appearance, and the tissues are reduced to a soft pulpy condition; the cell-walls are much swollen, faintly stratified, and separate from each other along the middle lamella. The decaying mass is infested with bacteria, but the most careful microscopic search has failed to detect any fungoid hyphæ. The rottenness can be readily introduced into a sound root by inoculation at a wounded surface; from this point the decay spreads rapidly through the root, the leaves gradually turn yellow, and in about fourteen days the entire plant has succumbed. Among the bacteria found in the rotten mass one has been isolated, which, when sown from a pure culture on turnips, under sterile conditions, induces all the characteristic effects of the "white-rot."

The bacterium, which has a single polar flagellum, was described by the author under the name Pseudomonas destructans. It occurs in the form of short rods about $3 \mu$ long by $8 \mu$ broad, with one polar flagellum; it rapidly liquefies gelatine, forming circular whitish colonies. The organism is parasitic on turnips, potatoes, carrots, but not on beetroot, forming a cytase.

Mr. Harold Wager gave an account of the phosphorus containing elements in yeast. By using the method of Macallum for the determination of phosphorus in cells, which consists in the formation of a precipitate by means of a nitric acid solution of ammonium molybdate and subsequent coloration by mean of the reducing agent phenylhydrazine hydrochloride, the author has been able to demonstrate that the phosphorus reside in a definite organ of the cell, which has been described as a nucleus by various observers. This affords, therefore, additional evidence in favour of the nuclear nature of the body.
Prof. Ward contributed some notes on methods for use in the culture of algæ. The notes were of the nature of suggestions, the experiments being still in progress; but the author gave an account of the work in hand with a view to interest those engaged in investigations involving the cultivation of algæ.

If agar is swollen in dilute acetic acid, and then washed very thoroughly, it can be used, mixed with the necessary culture fluids, as a convenient medium for the growth of some algæ, as Beyerinck had already observed.

The author has succeeded in separating algæ by the following methods :-

The algæ are shaken up in a sterilised nutritive mineral solution, mixed rapidly with silica jelly, also sterilised, and poured into glass dishes. With species of Oscillaria and of Palmella the author has observed growth in hanging drops of this silicajelly medium under high powers.

Another device is as follows :- Shake the algæ up in the nutritive solution and rapidly mix with sterilised plaster of paris and pour into dishes. The fixed algæ grow in situ in some cases, but others appear to be too sensitive for such treatment.

Experiments have also been made as follows, with some promise of success:-The algæ are shaken up in the culture medium, and a large quantity of lime-water quickly added. Carbon dioxide gas is then passed rapidly through, and the algæa are thrown down with the precipitate of calcium carbonate; this is poured into dishes as if it were plaster of paris. Perhaps this method could be utilised in the study of calcareous algæ, but with some forms it appears too drastic. One drawback is the difficulty of obviating the use of unsterilised materials.

In illustration of the application of the methods, Prof. Ward described some observations of the growth of Oscillaria tenerrima in hanging drops of silica-jelly. The growth of a single filament was followed for more than a week, and the curve showed that growth ceased during the hours of darkness, and was coincident with assimilation during the day. The author also obtained "light-figures" by exposing plates of green algæ, covered with stencil letters, to various intensities of daylight reflected from mirrors. When the light was not too strong, a green letter on a colourless ground was formed, but with intense illumination the exposed algæ were killed, while those in the covered area, illuminated only by diffuse light, were able to grow ; the result was a colourless letter on a green ground.

Mr. W. G. Freeman (Royal College of Science) contributed a note on the Anabaena-containing roots of some Cycads. The author drew attention to the manner in which the roots occur on various species of Cycads growing in very poor soil in the Royal Botanic Garden, Peradeniya. In most cases a dense coralloid mass of specialised fleshy roots was found encircling the stem; in others-e.g. Macrozamia Peroffskiana-normallooking lateral roots ran horizontally beneath the ground, giving off the special algæ-containing roots at intervals. These primary lateral roots may be apogeotropic for a time, but after bearing the Anabaena-containing masses they resume a normal habit and grow downwards.

Mr. E. J. Butler (Queen's College, Cork) communicated a note on a mixed infection in Abutilon roots. The roots of seedlings of Abutilon hybrids in the plant-houses of Queen's College, Cork, presented tuberoid enlargements due to, at least, two parasites - a Nematode and an Ascomycete. (I) The Nematode is a Heterodera, apparently not identical with $H$. Schachtii. All stages of the life-history were worked out by the author. (2) The Ascomycete is a new Thielavia, which the author named T. Hartogii, differing from $T$. basicola in its more abundant sporidia in each pseudo-sporangium and dark green chlamydospores. (3) A fungus, coexisting with (I) and (2), whose unseptate hyphre, "cellulose" wall and reproductive bodies recall Peronosporeæ, has been partially studied.

\section{PTERIDOPHYTA.}

Prof. Bower read a paper on fern sporangia and spores, in which he gave an account of the results of his recent investigations described at a meeting of the Royal Society on April 20 (Proc. Koy. Soc., vol. lxv. p. 96, 1899). Prof. Bower suggested the following classification of the ferns based on ( $I$ ) the relative time of appearance of sporangia of the same sorus, (2) certain details of structure of the sporangium and its stalk, (3) the orientation of the sporangia relating to the whole sorus, (4) the potential productiveness of the sporangium as estimated by its spore-mother cells, and the actual spore-output.

NO. I 568, VOL. 6I] 


Simplices $\left\{\begin{array}{l}\text { Marattiaceæ } \\ \text { Osmundaceæ } \\ \text { Schizæaceæ } \\ \text { Gleicheniaceæ } \\ \text { Matonineæ } \\ \text { Loxsomaceæ } \\ \text { Hymenophyllaceæ } \\ \text { Cyatheaceæ } \\ \text { Dicksonieæ } \\ \text { Dennstædineæ } \\ \text { The bulk of the } \\ \text { Polypodiaceæ }\end{array}\right\}$ Leptosporangiatæ.

Mr. L. A. Boodle (Jodrell Laboratory, Royal Gardens, Kew) gave an account, illustrated by numerous microphotographs, of his researches into the stem-structure in Schizaeaceae, Gleicheniaceae, and Hymenophyllaceae.

There is a wide difference between the types of stem-structure shown by the different members of the Schizaeaceae. Lygodium has a stele in which the xylem forms a central solid mass and is surrounded by a continuous ring of phloem, pericycle and endo. dermis. Aneimia Phyllitidis has a ring of separate bundles (or steles); Mohria resembles Aneimia Phyllitidis in type. Certain species of Aneimia, e.g. A. mexicana, have in the internodes a complete ring of xylem bounded on the inner and outer side by a ring of phloem, pericycle and endodermis, with a central pith. Schizaea has a ring of xylem surrounding a central pith, but no internal phloem or endodermis.

The above four genera, which make up the Schizaeaceae, agree in having a stem protoxylem, which is not well marked. Lygodium, Aneimiza, and Mohria are exarch; in Schizaea, however, the relative position of the protoxylem has not been made out with certainty.

The Aneimia type (which corresponds with that of a mature Polypodium) may be regarded as the more specialised type among the Schizaeaceae, and Lygodium (which corresponds in structure with the base of the stem of Polypodium) as the more primitive type.

The Gleicheniaceae and Hymenophyllaceae also include forms with a solid central mass of xylem, but diftering in some details from Lygodium. Gleichenia is mesarch and closely resembles the fossil genus Heterangium. In the Glercheniaceae the only advance on the Lygodium type is found in Platyzoma, in which there is a ring of xylem surrounding a central pith, as in Schizaea, but differing from the latter plant in having an inner endodermis.

In the larger species of Trichomanes there is a solid xylem. mass, but with a group of parenchyma in connection with the one or two more or less centrally placed protoxylems. In Hymenophyllum the corresponding parenchymatous mass is large in proportion to the amount of xylem. In the smallest species of Trichomanes the stele of the rhizome takes the form of a collateral bundle. The protoxylem of Trichomanes spicatum, unlike the other species examined, resembles that of the Schizaeaceae.

The solid stele may be regarded as primitive, the Aneimia type being derived from it by the following steps :-

(I) Solid central xylem-mass surrounded by phloem, \&c.

(2) Ring of xylem surrounding a central pith.

(3) Ring of xylem with internal phloem, endodermis, and pith.

(4) Ring of separate bundles formed by the breaking up of the above vascular ring, owing to large leaf-gaps.

\section{Physiology.}

Sir William Thiselton-Dyer described some experiments of far-reaching importance, made by Prof. Dewar, on the influence of the temperature of liquid hydrogen on the germinative power of seeds. The most important was one in which five kinds of seeds, varying in size and composition, were immersed for six hours in liquid hydrogen. The temperature to which they were cooled was $-453^{\circ} \mathrm{F}$. below melting ice. They were subsequently sown at Kew, and germinated readily without exception (vide Proc. Roy. Soc., vol. 1xv. p. 36I, I899).

The bearing of the experiment on the accepted conception of protoplasm gave rise to some discussion. Protoplasm is conceived to consist of physiological molecules, the properties of which cannot be explained with our present knowledge of either physics or chemistry. They are in a state of constant kinetic energy based upon equally continual metabolic change.
But if it is admitted that the latter is impossible at very low temperatures, the former must cease and the evidence of life disappears. The physiological molecule becomes purely static ; its energy is wholly potential, and in fact it becomes, as Prof. Casimir De Candolle has pointed out, analogous to an explosive.

Mr. Francis Darwin described some exceedingly interesting investigations on the localisation of the irritability in geotropic organs. The seedlings of Setaria, Sorghum and some other grasses are remarkable for possessing a hypotcotyl or stalk-like part intercalated between the grain and the cotyledon. Rother has shown that while the hypocotyl is the motor apparatus, the sensitiveness to light resides in the cotyledon, which transmits a stimulus to the hypocotyl, and this results in curvature. The author showed that the cotyledon is also a sense-organ for gravitation, the stimulus which leads to geotropic curvature being in like manner transmitted to the hypocotyl. If a seedling of Sorghum or Setaria is fixed by its grain to a support so that the hypocotyl is horizontal, it bends upwards apogeotropically till the cotyledon is vertical ; it then ceases to be geotropically stimulated, and no longer transmits an influence to the region of curvature. But if the conditions are reversed, if the seedling is supported by its cotyledon (which is fixed in a horizontal position) while the hypocotyl projects freely, the result is other wise. The hypocotyl begins to curve upwards just as in the first experiment, but it does not cease to curve when the free end points vertically upwards; the curvature continues in definitely, so that the hypocotyl curls into a spiral of three or four rings. This can only be explained by the assumption that the geotropic sensitiveness resides in the cotyledon, and that since the cotyledon remains horizontal it continues to be stimulated and transmits a continuous influence to the motor part of the seedling.

On Saturday morning some of the members of the Botanical Section took part in a joint discussion with the Chemical Section on symbiosis. Prof. Marshall Ward introduced the sub. ject by an able account of the meaning and significance o symbiosis, as illustrated by numerous instances of symbiosis and symbiotic fermentations afforded by various vegetable organisms. After describing particular cases of symbiosis, more particularly of symbiotic fermentations, Prof. Ward dealt with the physiology of symbiosis.

Mr. J. Parkin (Cambridge) communicated some isolated observations bearing on the function of latex.

The author has lately returned from a year's sojourn in Ceylon, where he has been acting as scientific assistant to Mr. Willis, the Director of the Royal Botanic Gardens. During his time there he has been principally engaged in investigations on caoutchouc-yielding trees, chiefly Hevea brasiliensis (Para Rubber) and Castilloa elastica, var. (a Central American rubber. tree). The results of this research are contained in a recentlypublished circular of the Royal Botanic Gardens, Ceylon, entitled "Caoutchouc or India-rubber," intended primarily for those interested in rubber cultivation.

The author drew attention to some of the observations and experiments recorded in the circular, which, besides their practical value, have a general botanical interest; he also recorded other observations which may throw light on the functions of laticiferous tissue.

The points treated of in the paper were grouped under six sections :-

Section I. dealt with the coagulation of the latex of Hevea.

Section II. contained observations and remarks relating to the carbohydrates of latex.

In Section III. reasons were given for thinking that in some caoutchouc trees the latex of the young stems and leaves differs in composition from that of the trunk and main branches. While the latter yield rubber free of stickiness, the former give a somewhat viscous substance with feeble elasticity. Such is the case with Hevea, Castilloa, Landolphia Kirkiz, \&c.

Section IV. treats of an important fact connected with the tapping of Hevea trees-namely, that wounding the bark causes a greater flow of latex from subsequent injuries.

In Section. V. a peculiarity in the exudation of latex from the severed base of the petiole of Hevea brasiliensis and Plumiera acutifolia was described and discussed.

And in Section VI. a special laticiferous system in the im. mature seed of Hevea brasiliensis was described.

The paper concluded with general remarks and suggestions on the origin and functions of laticiferous tissue.

No. I 568 , vOL. $6 \mathrm{I}]$ 
Mr. R. H. Biffen (Cambridge) contributed some notes on india-rubber. Caoutchouc is a constituent of the latex of many plants belonging chiefly to the Euphorbiacer, Apocynacere and Urticaceæ, that is, of plants characterised by the possession of laticiferous cells as distinct from vessels. Caoutchouc occurs as small particles in latex; if a reagent is added which will cause coagulation, the particles run together in strings and form a moss-like mass of rubber with the watery portions of the latex entangled within it. Two physical processes are now being used. (I) The latex, mixed with water, is strained and churned; the thick cream which rises to the surface is pressed through rollers and converted into rubber. (2) The author's process consists in separating the rubber with a centrifugal apparatus. Details are given in the paper regarding the chemical properties of the different kinds of rubber obtained from Hevea, Castilloa, Manihot, Ficus, Hancornia, Kicisia, Artocarpus and Ciusia. The author also raises some questions of theoretical interest with regard to possible relations between caoutchouc, starch and resin-bodies, and indicates lines for further inquiry.

\section{Flowering Plants, \&C.}

Mr. J. C. Willis, of Peradeniya, Ceylon, read a paper of exceptional merit, illustrated by numerous lantern slides, on the morphology and life-history of the Indo-Ceylonese Podostemacer.

The paper read was an abstract of a forthcoming monograph of the Indian and Ceylon species of this very remarkable order of water plants, in which the various species will be described in detail both morphologically and ecologically. A few typical species were described and their life-history explained, showing the extraordinary modifications which the vegetative system has undergone to suit the needs of life in rising and falling water and in rapid currents. The vegetative organs consist largely of modified roots forming thallus-like bodies, and bearing leafy or floral endogenous shoots, and branching themselves in an exoor endo-genous manner. The conclusion was drawn that the endo- or exo-genous origin of an organ or a branch is a phenomenon of an adaptive nature in these plants, and to a large extent in others also. The adaptive modifications of the structure, such as the gradual reduction, through a series of forms, of the shoots and leaves, the increased multiplication of the shoots by vegetative budding, the reduction of the number of flowers per shoot, and the change to anemophily, the increased dorsiventrality and other characters, were shown to be rather correlated with the rise and fall of the water than with the velocity of the stream. In conclusion, some of the more general questions of morphology were discussed in the light of the observations made on these plants.

Prof. Douglas Campbell (California) gave a short account of work in progress on the development of the flowers and embryos of various species of Araceæ.

The materials for the author's investigations were collected mostly in Jamaica, and include species of Dieffenbachia, Aglaonema, Philodendron and Anthurium. A study was also made of Lysichiton of Pacific North America.

A studiy of the development of the ovule indicates that the primitive form is axial, as in other low monocotyledons; the early development of the embryo-sac follows the ordinary type. Later there is a multiplication of the antipodal cells, and the sac becomes filled with endosperm at an early stage. The ovule is often massive, and there is a marked development of mucilagesecreting hairs upon the funiculus and the base of the nucellus. In all forms so far examined the embryo is destitute of a suspensor, and the cotyledon is very large, sometimes suggesting the scutellum of the grass-embryo.

The forms with a single carpel are probably most primitive and most nearly related to the other low monocotyledons.

Mr. G. Dowker gave a description of the sand dunes between Deal and Sandwich, with remarks on the flora of the district.

The author in this paper gave an account of the formation of the dunes and mud-banks, claiming for them the reclamation of the large tract of sand from the sea, mostly since the Roman occupation of Britain. He referred to the Acts of Parliament passed prohibiting the destruction of the mat grass, which contributed sc largely to the preservation of the hills, and lamented that nothing was done to prevent the wholesale gathering of Sea holly by men who ruthlessly destroyed it by taking it away to sell. He recounted his long experience and knowledge of the district, dating back to his schoolboy days with the Rev. J.

$$
\text { NO. I } 568 \text {, VOL. } 6 \text { I ] }
$$

Layton, a distinguished botanist of Sandwich. He particularised the following rare or characteristic plants as denizens of the hills : Allium vineale, A. compactum, Poa bulbosa, Hippophae rhamnoides, Silene conica, Orobanche caryophyllacea, Lepidium latifolium, and on the salt marshes, Atriplex pedunculata, Frankenia levis, Aster Tripolium, and Polyponon monspeliensis. The author added a list of over 300 species of flowering plants to be met with in the district.

Miss Dale (Cambridge) presented a paper on intumescences of Hibiscus vitifolius.

The plants on which the observations were made were grown, directly or indirectly, from seed from Somaliland. The intumescences, which vary in size and shape, occur on the leaves, stems, green parts of the flower, and on the young fruit. Some are entirely colourless; others are green at the base. On the leaf the intumescences are either purely epidermal or partly subepidermal ; and on the stem the outgrowths are more complex and usually larger.

A number of seedlings were planted in separate pots, and allowed to grow under identical conditions. They all developed intumescences, and were all very much alike. When each had about nine or ten leaves, and was beginning to flower, the plants were placed under different conditions, and examined at the end of six weeks.

The experimental evidence points to the conclusion that the intumescences are pathological, and are due neither to insects nor to fungi, but to the direct effects of environment. The formation of outgrowths appears to be caused by excessive moisture combined with a high temperature. If the temperature is low the plants do not appear to have strength to form them. The production of outgrowths seems to be a response on the part of the plant to insufficient transpiration.

\section{Fossil Plants, \&c.}

Prof. Bertrand (Lille) described the structure of a stem of a ribbed Sigillaria. The specimens of Sigillaria hitherto described anatomically are species with a smooth bark, but no account has so far been published of the structure of an undoubted Sigillaria belonging to the Rhytidolepis section. The species described by Prof. Bertrand exhibits external characters recalling those of Sigillaria elongata. The primary wood, which forms a continuous ring, agrees with that of the stems previously described as Diploxylon; it is enclosed externally by a zone of secondary wood. The primary xylem is characterised by the prominent ridges or points on its external face, the projecting points corresponding with the grooves on the surface of the sten. In the immediate neigh bourhood of the origin of a leaf-trace, the small tracheal elements form a median band in the middle of a sinus on the face of the corona. Each leaf-trace passes outwards through a medullary ray of the secondary wood; it consists solely of primary elements. The author compared his specimen with Sigillaria spinulosa and with Diploxylon stems from Halifax, Oldham and Burntisland. The central cylinder of the ribbed Sigillaria differs from that of a Phanerogam in the manner of origin of the leaf-traces, and in the structure and centripetal development of the primary wood.

Prof. F. E. Weiss (Manchester) communicated a paper on a biserial Halonia belonging to the genus Lepidophloios.

At the Bristol meeting of the British Association, Dr. D. H. Scott exhibited photographs of this Halonia from the Hough Hill Colliery, Stalybridge, and pointed out the agreement of its structure with that of Lepidodendron fuliginosum of Williamson. Dr. Scott had generously allowed the author to undertake the further examination of the specimen, and this confirmed the identity of the internal structure of the Halonia with that of Williamson's Lepidodendron fuliginosum.

The same structure is shown also by stems of the ordinary multiseriate Halonias, which, as Kidston and Potonié have shown, belong undoubtedly to the genus Lepidophloios. Stems, therefore, showing the structure of Lepidodendron fuliginosum, Williamson, should be referred to the genus Lepidophloios.

The fruiting branches of this genus, however, termed Halonia, or halonial branches, have usually a number of rows of spirally arranged tubercles. The Hough Hill Halonia has only two rows of tubercles; hence it would by some palæobotanists be classed as Ulodendroid, but it seems better to call it a "biserial Halonia," since the name of Halonia has been reserved by Kidston and others for the fruiting branches of Lepidophloios, and also because its elevated tubercles distinguish it from the usually depressed Ulodendroid scars. 
The author described two specimens of biserial Halonias showing on the surface Lepidophloios leaf-scars, in support of the view that the Hough Hill specimen may be regarded as a fruiting branch of Lepidophloios.

Mr. A. C. Seward showed some microphotographs, and gave a brief account of a new genus of Palæozoic plants.

The description of this genus, which represents a new type of Cycadofilices, was founded on a single specimen in the Binney Collection of Coal-measure Plants. The specimen consists of a small piece of stem, unfortunately without the cortical tissues, with the structure of the primary and secondary wood very clearly preserved. A strand of primary xylem, I $9 \mathrm{~cm}$. in diameter, occupies the axial region; this consists of large isodiametric or slightly elongated tracheids with multiseriate bordered pits, associated with parenchymatous tissue; the narrow protoxylem elements occur at the margin of the primary stele, which is, therefore, of exarch structure. Surrounding the primary stele there is a broad cylinder of secondary wood exhibiting anatomical features characteristic of Cycadean stems. Leaftraces, consisting of long tracheids intermixed with parenchyma, are given off from the periphery of the primary strand.

The features of most interest in the anatomy of this stem are (I) the manner of origin and behaviour of the leaf-traces; (2) the exarch structure of the primary xylem; and (3) the structure of the large primary tracheids. The author placed the genus among the Cycadofilices, and compared it with Heterangizm and other Palæozoic genera, also with Lygodium and other recent plants.

Mr. A. C. Seward also gave a résumé of his recent work on the Jurassic flora of Britain. The Lower Oolite rocks exposed in the cliff-section between Whitby and a few miles south of Scarborough have long been famous as affording rich collections of fossil plants, which enable us to form a fairly accurate idea of the chief characteristics of the Jurassic flora. Plants from the Yorkshire coast are abundantly represented in most of the English museums as well as in continental collections. The Ferns and Cycadean genera constituted a large proportion of the vegetation, with an abundance of one or two species of Equisetites and a few conifers; no trace of undoubted Angiosperms has so far been discovered. The account of the flora includes a description of the more important types, a general comparison of the English species with recent plants, and remarks on the characteristics and distribution of the Lower Oolite floras.

The same author, in conjunction with Miss J. Gowan, gave an account of the morphology and geological history of the maidenhair tree (Ginkgo biloba). The chief points dealt with in the paper may be summarised as follows :-

(I) Ginkgo bilboa. - The history of our knowledge of Ginkgo; its external features and peculiarities; the variability in form and structure of the leaves; the structure and morphology of the male and female flowers; pollination and fertilisation of the ovule; the development and structure of the embryo; the anatomy of the seedling and adult plant; comparison of Ginkgo with other genera, and its place in the plant-kingdom.

(2) Fossil Ginkgoaceae.-A general consideration of the evidence available towards an account of the past history of. Ginkgo and closely allied plants; a comparison of Ginkgo with various fossil types from Palæozoic, Mesozoic and Tertiary horizons the geographical distribution of Ginkgo during the Mesozoic and Tertiary epochs.

\section{UNIVERSITY AND EDUCATIONAL INTELLIGENCE}

CAMBrIDGE.-The following is the speech delivered on November 9 by the Public Orator, Dr. Sandys, in presenting Prof. Somerville for the complete degree of Master of Arts honoris causa.

Agri culturae professorem nostrum primum, auspiciis optimis nuper electum, Universitatis totius nomine libenter salutamus. Salutamus virum, primum per sex annos rei rusticae experientia probatum, deinde per quinquennium scientiae studiis et domi et peregre excultum; virum non modo nomismate non uno honorifice donatum, sed etiam doctoris titulo inter Monacenses summa cum laude ornatum; virum denique et Societati Regiae Edinensi et Societati Linnaeanae Londinensi in perpetuum adscriptum. Olim inter Edinenses primus rei silvestris pr.eceptor, deinde in Universitate Dunelmensi agri culturae professor primus constitutus, nuper eodem cum titulo e Boreali Britanniae regione ad nos feliciter devectus est. Viri talis auxilio rei rusticae

No. 1568 , vOL. 61$]$ scientia, olim ab ipso Tullio senectutis inter voluptates numerata nunc demum etiam iuventutis nostrae inter studia locum diu sibi debitum sine dubio vindicabit.

\section{Duco ad vos Willeimum Somerville.}

Mr. Shelford Bidwell, F.R.S., has been a pproved for the degree of Doctor of Science.

An Isaac Newton Student in Astronomy and Physical Optics will be elected next term. The studentship is worth 200 l. a year for three years. Candidates must be Bachelors of Arts who are under the age of twenty-five. Applications are to be sent to the Vice-Chancellor between January I6 and 26, I900.

Prof. Somerville will give an inaugural lecture on "Some aspects of the bearings of Science and Education on Practical Agriculture" on Friday, November 24, at noon, in the Chemical Theatre.

A report proposing a new scheme for the Mathematical Tripos has been issued to the Senate. Among other changes, it suggests the abolition of the time-honoured "order of merit" in the Tripos list.

By the will of the late Mr. Cornelius Vanderbilt, of New York, Yale University receives I00,000 dollars, and Vanderbilt University 50,000 dollars.

Sir Michael Hicks Beach, Chancellor of the Exchequer, spoke on the subject of commercial education at the Mansion House on Friday last. In the course of his remarks he referred to the University of London, and said that the reorganisation offered an opportunity to a "pious founder" to graft upon the University a faculty of commerce in which the study of all subjects belonging to commercial education shall be encouraged He pointed out that there is no part of the world in which there are greater chances at the present time of pushing our trade and commerce than in the empire of China, and yet there is no civilised part of the world the language and history and customs of which are so absolutely unknown to the vast majority of our people. If it were possible to expend a comparatively small sum in extending a knowledge of these things in connection with a faculty of commerce in the University, more might be done to promote British trade and commerce in China than will ever be done by extracting concessions from the Government of China, many of which, the speaker added, will confer benefit upon nobody except the promoters who try to float them into companies.

THE ninth annual report of the Technical Instruction Committee of the City of Manchester shows that steady progress was made during the year ending last mionth. The large scale of the operations of the committee may be judged by the fact that the payments made in connection with the Municipal Technical School amounted to $16,796 l$. The expenditure on capital account to meet various charges in respect of the new building was $26,53 \mathrm{I} l$., making a total sum of $97,06 \mathrm{r} l$. expended for this purpose up to last March. The receipts from the Exchequer Contribution Account (Customs and Excise) were $15,567 l$. and the amount raised from the rates was $7585 l$. The new estimates provide a sum of $33,000 \%$. for building purposes during the current year in connection with the technical school in course of construction. The total sum now borrowed upon capital account for providing technical schools in Manchester is $140,000 l$. When the new municipal technical school is com. pleted, Manchester will possess one of the finest buildings in the country for carrying on the work of technical education. For the equipment of the building alone a loan of $59,025 \%$. has been sanctioned by the Local Government Board. Referring to the subject of secondary education, the committee remark :"The enactment during the past session of Parliament of a measure establishing a Board of Education cannot but be satisfactory, however much it may fall short of finality, to all those who are sincerely interested in the advance on sound lines of secondary and technical education, since it creates for the first time a real and responsible Minister of Education, and unifies the various branches of education-elementary, secondary and technical - under one controlling authority. It will unquestion. ably promote the efficient working of the technical schools by the measures which it will take to place the secondary education of the country, now so lamentably deficient, upon a sound and satisfactory basis, without which no technical education worthy of the name can be carried on." 